\title{
Evaluation of the Effect of Privatization on Financial Development and Company Growth
}

\author{
Mehdi Mardani ${ }^{1}$, Maryam Abbasi Athar ${ }^{2}$, Seyed ghasem ghoreishi kadijani ${ }^{3}$, Behnam Shokri ${ }^{4}$ \\ ${ }^{1}$ Department Of Accounting and Management, Semnan Branch, Islamic Azad University, Semnan, Iran \\ ${ }^{2}$ Department Of Social And Economic Sciences, Al-Zahra University, Tehran, Iran \\ ${ }^{3}$ Department Of Accounting and Management, Islamshahr Branch, Islamic Azad University, Tehran, Iran \\ ${ }^{4}$ Department Of Accounting and Management, Parandak Institute of Higher Education,Tehran, Iran
}

\begin{abstract}
Privatization is the process of assigning priorities to the market mechanism and making them market-oriented. It includes a broad spectrum which one side of it is complete privatization and other side of it restructuring of government-owned enterprises. Therefore, the objective of this study is to evaluate the effect of privatization on financial development and company growth in 5-year period between the years 2013 and 2017 in Tehran Stock Exchange. The research sample consisted of 123 listed companies in the Tehran Stock Exchange. They were selected based on knockout sampling method. This research is an applied study in terms of objective and correlational in terms of the relationship between the variables. The method of research is descriptive-survey and the logic of research implementation is the inductive, and the research data are retrospective quantitative. To examine the hypotheses, Durbin-Watson, Limmer and Hausman tests and panel data regression were used. The results showed that privatization has a significant effect on financial development, and examining the hypotheses showed that privatization has an impact on company growth.
\end{abstract}

Keywords: privatization, financial development and company growth.

\section{Introduction}

Privatization is a process in which the government provides the conditions for transfer its duties and assets to the private sector. The privatization means the establishment of a new system based on market mechanisms, and as a result, transformation in different dimensions of the economy. Privatization in the concept of cultural dissemination means providing the conditions for increasing people involvement at all levels in the economic affairs of the community. Thus, privatization is a comprehensive and diverse term, refers to the operational and financial control of public institutions and transferring them to the private sector. In other words, privatization involves elimination of any kind of control and intervention in the establishment of the supply and demand mechanism. The transfer of ownership or control of economic enterprises from the government to the private sector can also be accepted as a definition for privatization (Mahdi, 2013). Nowadays, privatization is one of the ways considered by the governments to achieve a desirable economic growth .Privatization and the reduction of the ownership of government (downsizing) in economic activities are a major part of the policies of moderating the company structure. The expansion of privatization will not only increase the involvement of the non-government sector in the administration of business affairs and improves the entrepreneurship and innovation, but also will also enable the government to do research needed to adopt macroeconomic policies.

It should be noted that there are many barriers in this regard and the key role of the government in eliminating these barriers through its correct and logical policies should not be ignored. The conditions for growth and development of the re-structured organization should be provided by applying changes in the way of management in the privatized organizations (Shafiei and Zaratpisheh, 2012). Privatization affects financial performance of the companies. The evaluation of the unit economic performance, without considering the business characteristics and the conditions governing its markets and services, regardless of the status of unit evaluated in the country's economic system and structure, will not be fruitful. Nowadays, managers potentially pay attention to mechanisms through which their performance is being judged. They seek information on the relationship between their reward plans and their performance (Fama, 1980). Although classical theory emphasizes on limiting government intervention in economic affairs, intervention in the economy has increased over the decades after the end of the Second World War to the extent that the government played an active role similar to the program economies through its executive levers (government-owned enterprises) in most of the free and mixed economies. Industrial countries achieved relative success through macroeconomic policies during the 1950s 


\section{"Evaluation of the Effect of Privatization on Financial Development and Company Growth"}

and 1960s. For this reason, much attention was not paid to the limited criticism to government intervention in the economy at that time. At the end of the 1970s, we experienced numerous economic problems and continuous failures in economic policies at least in the Western world, provided the conditions for criticism and doubt on the government intervention in the economy and determining the appropriate size of government intervention, monitoring and guiding in the economy .Accordingly, theoretical controversies in the scientific communities on the government intervention, the persuasion of the managers and executive political decision makers of the countries to inefficient allocation of production resources due to the expansion of government size and the idea of revision in the share and size of government intervention became serious. Finally, at the end of the 1970s and early 1980s in the UK, followed by other industrialized countries and somewhat in developing countries, the issue of reducing the government intervention in order to resolve the disputes and differences and motivations for their emergence was considered seriously. After the end of the imposed war and the beginning of the first five-year economic, social, cultural and political plan in Iran, privatization policy was introduced as one of the important components of Iran's economic policy and the first legal action to limit the size of government intervention in the economy and involvement of private sector in economic activities was approved (Mahdi, 2013). The goal of privatization policy is to enhance the efficiency of activities, allocating resources, and expanding public participations in various manufacturing and business sectors, including development plan policies. Privatization is a new approach to the market system to compensate the consequences of a government failure in economic activities, which any negligence in this regard will undoubtedly lead to other failures in the economy (Ahmadi, 2011). The growth and development of stock companies led to the emergence and increase of a group of the capital owners over time, which they were not directly involved in the management of companies, but they guided and monitored the company's affairs through the selection of the board of directors. This new development and transformation created a new group of professional managers who had either no share or fewer shares in the capital of the institutions they managed. Accordingly, management of the institutions was separated from their capital ownership. In the competitive structure of the market, managers are faced with a variety of choices, which have an effect on the performance evaluation and profitability. Recognizing the factors affecting the profitability, income and performance of companies is considered a challenge in these markets. In studies conducted by the Industrial Organization in the United States, market share and its growth were introduced as important criteria for performance evaluation (Arab Mazar Yazdi and Arab Ahmadi, 2011). Companies are now trying to maximize the value of the company and increase the income and profit investing to attract investors (Fakhari and Yousef Nejad, 2006). In addition, in industrial organization studies, company growth has been recognized as the important performance indices of the company. Financial development also affects the economic growth through two channels, including 1. Improving the productivity of production factors. 2. Formation of capital. With regard to the first channel, it can be stated that financial development can improve the efficiency of total factors of production and thus increase the growth of the factors by facilitating risk management, identifying projects with high efficiency and facilitating the exchange of goods and services through promoting an optimal allocation of capital (Levine, 1997). The effect of financial development on economic growth through the second channel is ambiguous. Financial development can increase the return on savings, which in turn has two substitution and income effects, and thus, by increasing or decreasing the savings, investment increases or decreases (Hao, 2006). In addition, one of the important features of the economic liberalization programs in the last few decades is the privatization of government-owned companies. The privatization is broad concept and defined in many ways in financial literature. Some authors have defined privatization as selling government-owned assets. Weiss (1988) states that privatization is a process for transferring or assigning ownership of an asset of the public sector to the private sector. Ramamurti (2000) emphasizes that the privatization is any action that transfers part or all of the ownership or control of the government-owned companies to the private sector. Finally, based on the World Bank definition (2005), privatization is taking the ownership of companies and institutions, economic resources and other assets from the government. The scope of privatization programs has been developed and it is being implemented in most of developed and developing countries, and is expected to continue in the 21th century (Miller, 2002). The World Bank's privatization database also reports more than 3000 privatization transactions in developing countries (Perotti and van Oijen, 1999).

Different countries usually have several general goals for implementing and following their privatization programs. These goals are:

- Increasing the government incomes

- Improving the economic efficiency

- Reducing the government intervention in the economy

- Expanding of ownership of shares (or corporate ownership)

- Increasing the competition (Karami and Bahrami, 2016).

Given what was stated above, this research aims to evaluate the relationship between privatization, financial development and company growth. In fact, this research aims to answer the following question: What is the effect of 
privatization on financial development and company growth?

Experiences of different countries and the studies conducted in Iran suggest that planned and public administrations have low efficiency. Given the history of public administration in the use of inefficient resources, the Islamic Republic of Iran needs to be aware of the effects of privatization and its effect on the performance of transferred companies in order to be able to use the results of these studies in planning and implementing the privatization plans (Eskandari \& Mirza Mohammadi, 2014). This issue is so important that the Iran's Parliament asked the Parliament Research Center in August 1997 to conduct comprehensive studies on the way of privatization and its effects in order to inform parliament representatives about the performance of the privatization policy. Paying attention to privatization process in developing countries suggests that these countries, like industrialized developed countries require government intervention in a period of economic growth. In most developing countries governments are not able to implement the privatization policies and strengthen the private sector properly due to the weakness of the government structure and the general weakness of the economic structure. In Iran, experts argue that lack of favorable conditions for the process of privatization has made it difficult to implement in different stages. This research was conducted with the aim of evaluating the effect of privatization on financial development and growth of listed companies in Tehran Stock Exchange with a resilient economy approach.

\section{Theoretical Foundations of Research Financial development indices}

Financial systems reduce transaction costs and improve resource allocation through functions of gaining information on investment opportunities, monitoring of investments, risk distribution, aggregation of savings, and facilitating the exchange of goods and services. Finally, it leads to economic growth. In order to depict the Iran's financial development in recent years (the third and the first two years of the fourth plan), we refer to different dimensions of the financial development indicator. The common criteria for financial development, including the depth finance and the share of credits granted to the private sector, do not reflect the concept of financial development and its functions well. Based on the studies conducted, financial development is a multi-dimensional concept that in addition to monetary and banking dimensions, it includes other dimensions and components such as financial sector freedom, quality of rules and regulations and supervision governing this sector, technological advances, and competition level and existing institutional capacities. The financial structure of a country is composed of different markets and financial products, and some limited criteria cannot cover all the necessary aspects of financial development (Dadgar and Nazari, 2013).
Financial development is a comprehensive concept expressed in six different dimensions.

- Development of the bank sector

- Development of non-bank financial sector

- Development of monetary and monetary policy-making sector

- Bank regulations and supervision

- Financial sector openness

- Institutional environment

Each of these dimensions is described below:

Development of the bank sector: In most economic systems, banks are the center of the financial and payment system and play a key role in the process of saving equipment, identifying investment opportunities and diversifying of the risk. Thus, the size, structure and efficiency of the banking sector are considered as an independent dimension of financial development. The banks' profitability, payment credits and easy access of private sector to bank credits are discussed in this sector. Based on studies conducted, the activity of banks in a competitive environment include less government intervention, less market concentration, and more possibility of foreign banks entering will increase the growth and efficiency. Development of non-bank financial sector: this sector examines the developments in the nonbank financial sector, development of capital resources and alternative financial services. This sector includes stock markets, mortgage financial institutions, securities markets, insurance companies, and pension funds. The diversity of products and diverse markets in this sector provide the conditions for transformation in the duties and tasks of system, enterprises and households to effectively improve their financing; equip the financial resources; monitor the management of financial sector, and distribute risks. Development of the monetary and monetary policy-making sector: In this dimension, in addition to the financial depth indicator, the extent to which governments use indirect monetary policy instruments, interest rate, the effectiveness of the monetary policymaker, as well as credit quotation are investigated.

Bank regulations and monitoring: Due to the information and failure of the market in financial transactions, proper control and monitoring are important aspects of financial development. Financial authorities prevent corruption in order to ensure the interests of depositors in the banking system. The monitoring of banks accurately, the degree of central bank independence and the transparency of financial and monetary information are measured in this dimension of financial development.

Financial sector openness: Another aspect of financial development is the rank and position of the domestic financial system in the transboundary transit of financial resources. The financial markets openness to capital inflow and outflow, proper exchange regimes, and restrictions on the exchange of financial assets or foreign exchange instruments of foreigners and residents are investigated in this dimension. 


\section{"Evaluation of the Effect of Privatization on Financial Development and Company Growth"}

Institutional environment: The legal and political environment plays a decisive role in the quality of service provided by the financial institutions. For example, in some developing countries, banks do not have high tendency to increase the loans, since inefficient judicial systems or corrupt political and administrative institutions prevent repayment of the loans. The quality of legal institutions, ownership rights, the quality of bureaucracy and the responsibility of the government affect the financial system performance. For this purpose, the institutional environment is considered as one of the dimensions of financial development. Therefore, financial development is not achieved solely by development in the banking, financial, and monetary dimensions. It depends on the degree of development in terms of bank regulation and monitoring, the degree of financial market openness and the institutional environment of the community. The most important elements of financial development are discussed here (Dadgar and Nazari, 2013).

\section{Evaluation of financial development indices in the bank sector}

The development of the banking sector, which is one of the major dimensions of financial development, can be explained by the following explanatory elements. The share of the non-government sector in the banking industry of Iran:

The law on the establishment of a non-governmental bank was approved in April 2000 with the aim of increasing the competitive conditions of banks, expanding financial markets and encouraging domestic saving. Until the end of the third plan, four non-governmental banks (Agtesad-e Novin, Karafarin, Saman and Parsian) and a non-bank credit institution (Development Credit Institution) started their activities. The non-government banks of Pasargad and Sarmaye started their activities in 2005. For the aim of indexing the rate of presence of non-government banks in the banking industry of the country, the share of deposits and credits allocated by these banks can the corresponding variables in the bank's network can be used. For this purpose, in this section, the ratio of deposits in nongovernment banks to total bank deposits and the share of debt balance of non-government sector to non-government banks from the total debt balance of non-government sector was used. With the start of the activities of non-government credit institutions in 2000, the share of deposits of these institutions began from $0.3 \%$, and it increased with the increase of the number of such institutions and the beginning of the activities of the non-government banks in 2002, so that it increased to $7 \%$ at the end of the year 2004 and $12 \%$ and at the end of 2005. This figure increased to $15.7 \%$ in the second year of the fourth plan. An increase in this ratio reflects the success of these types of banks in attracting public trust and attracting non-government sector deposits. The major factor in increasing this share and its increasing trend is the high rate of interest of deposits of these banks in comparison with government banks, increasing public trust and also a drop in stock indices. Moreover, the share of non-government sector debt balance to non-government banks from total non-government sector debt balance increased from $0.2 \%$ at the end of 2000 to $7.9 \%$ at the end of 2004 . This ratio increased by $2.12 \%$ and $13.8 \%$ during 2005 and 2006, respectively.

\section{The share of the non-government sector from bank facilities:}

The share of credits allocated to the non-government sector of the total credits is one of the indices used in many studies to measure financial development. The basis for using this indicator is that as the financial system drives more shares of the credits towards the private sector, its performance in functions such as evaluation of managers, selecting investment projects, management of risk and providing financial services will be more successful. To evaluate the wat of directing the credits to government and nongovernment sectors, the share of non-government sector debt balance to banks from the total government and nongovernment debt balance is used. The increasing trend of this ratio indicates an increase in the non-government sector's share of banking facilities in recent years. This ratio increased from $1.79 \%$ in 2000 to $8.85 \%$ at the end of the third development plan. During the first two years of the fourth plan, this ratio increased by 5.88 and 8.90 , respectively.

The ratio of assets of Banks and credit institutions to the assets of the banking system:

This component reflects the relative importance of depositary financial institutions. It seems that commercial banks are more likely active than the central bank in providing financial services of a type of risk participation and a variety of information services in the financial system. The index corresponding to the given component is the share of the share of domestic assets of banks (except the central bank) of the total assets of the banking system (including the central bank). The mentioned ratio followed increasing trend after a sharp decline in 2002 due to the increase in central bank assets.

Ratio of reserves of banks and credit institutions to total non-government sector deposits:

This component is obtained by dividing the total additional reserves of banks and credit institutions in the central bank as well as the funds available in the bank's funds on the total deposits of the non-government sector in the banks. This ratio reflects the amount of banks' resources to create credit and their ability in granting banking facilities. By reducing the reserves of banks in the central bank, their ability to grant facilities will increase. The ratio increased from $5.26 \%$ in 2000 to $6.16 \%$ percent at the end of the third development plan, indicating the greater ability of the banking network in financing economic enterprises and providing credit facilities. In spite of this decreasing trend, this ratio increased by $5.19 \%$ in 2005 due to the increase in 


\section{"Evaluation of the Effect of Privatization on Financial Development and Company Growth"}

the special deposit of one of the banks. However, this ratio decreased again in 2016 and decreased to $9.17 \%$ at the end of this year.

The degree of bank' concentration: due to the high costs of the banking industry, the banking industry cannot theoretically be a complete competition industry. Hence, the calculation and evaluation of the concentration indices indicating the degree of incomplete competition in this industry is common in studies. The degree of concentration in this sector corresponds to the share of the deposits of the first three banks, which has the largest share of deposits in the bank's network from the total deposits of the nongovernment sector in the banking network. A high degree of concentration can be an indicator of lack of competition and inefficiency in the banking network. The decreasing trend in the degree of concentration of banks from $5.62 \%$ in 2000 to $45 \%$ in 2006 indicates an increase in the competitive environment in the banking sector in recent years due to the entry of non-government banks into the banking sector.

Bank margin of profit: The difference in interest rate of facilities and bank deposits, known as margin of profit, is one of the criteria to evaluate the efficiency and profitability in a bank network. In this evaluation, the bank is considered as an economic enterprise that receives deposits as inputs of production and transforms them into credit facilities in the process of creating credit. Accordingly, bank margin of profit, which is the difference between the price of product and the input price of production for the bank as a manufacturing enterprise, indicates the intermediary costs of banks and one of the factors affecting the operating profits of banks. However, its high or low level cannot be an indicator for evaluating the efficiency of the banking network. The interest rate on short and long-term deposits and the interest rate of facilities in different sectors vary. Thus, the difference between interest rate of long-term deposits and the interest rate of facilities in government banks have been used to calculate the bank margin of profit. Accordingly, the bank margin of profit decreased from $9.4 \%$ in 2000 to $3 \%$ in 2006.

Value added of services of monetary and financial institutions: Value added of services of monetary and financial institutions are a combination of the value added of banks and non-bank credit institutions, the value added of insurance services, as well as the value added of financial intermediary (Stock Exchange). As about 85 percent of the value added of service of monetary and financial institutions includes the value added which is created by the banking sector, the ratio of value added of services of monetary and financial institutions to the value added of the service sector can be used as an indicator of the expansion of services of banking sector in the economy. The increasing trend in this ratio suggests the expansion of the services of monetary and financial institutions in recent years in comparison with other services. This ratio increased from $3.6 \%$ in 2000 to $9.4 \%$ in 2006.
Banking network efficiency: One of the indices of the banking network efficiency is the ratio of facilities granted to deposits. This ratio reflects the ability of the financial system in using deposits to grant facilities. Due to the lack of access to the net data of the facilities granted, in evaluation of the efficiency of the bank's network, the ratio of the non-government sector debt balance (without profit and income of the coming years) in the bank's network to non-government sector deposits is used. This ratio increased from $67.7 \%$ in 2000 to $87.2 \%$ in 2006 . This ratio is influenced by the changes in the ratio of legal deposit as well as the overdrawing of banks from the central bank (Dadgar and Nazari, 2013).

\section{Capital and its role in development}

As capital is derived from the accumulation of net investments in previous periods, in the definition of capital, it is stated that capital is an accumulation of a part of production of a community that does not become the final product consumed. Most of development scholars argue that the role of capital in the process of economic growth is essential, since in this process, the community faces with increasing population and, consequently, increased substitution of depreciated capital, and maintaining the level of national income at a level equal to last year, we require an investment in the long term, the formation of capital is an inseparable part of the economic activities of any country. In general, the sources for funding the capital are either domestic or foreign.

\section{Land and its role in development}

In general, land is the above the ground, the surface of the ground and the underground (underground resources). Above the ground means climatic conditions of ground. According to theorists, the hot and cold weather causes a reduction in work power, an increase in impatience. As a result, it is a barrier for humans in their endeavor to advance economically. With an emphasis on the development of all countries with temperate climate, Huntington considers the role of this facto decisive in the book of main causes of civilization. It has a positive role in the production of agricultural products, the availability of suitable land, and the availability of rivers and access to the sea in terms of reduced transportation costs. It is also an effective factor in facilitating communication in a country. In most of third world countries, the lack of a proper and coherent communication network is one of the barriers for economic growth. Underground resources can play a major role directly and indirectly in the growth of production. Along with economic growth, the consumption of many underground resources, energy materials, iron and other metals, cement and other building materials, and so on increases, so that having rich underground resources can effectively contribute to the process of growth. In a developed society (such as today's Japan, due to access to the other three factors, the role of the fourth factor that is land is less than that of the developing society. 


\section{Technology and its role in development}

The concept of technology economic development, as a part of macroeconomics, is much broader. In the general economics, some economists consider technology as a direct factor in production, while others consider it as a timedependent factor that cannot be created by other factors of production. Technology is in fact changes in it. In any production, the existing production method is called the technology of that activity. Change in the technology not only might increase the production, but also can lead to a change in its quality or even the creation of new goods.

\section{The role of work force in development}

In theory of economics and in the work force subject as one of the factors of production, what is usually considered is the quantity of work force. In the subject of economic development and the work force as one of the factors of economic growth, the main issue is the quality of work force rather than its quantity. The quality of the work force is so important that some development economists, such as Kuznets argue that the difference in the level of economic growth among the countries can be explained by the difference in the quality of work force in these countries. The technical skill of the work force is not just technical knowledge and it includes the concepts such as interest in the product produced, having a collective work spirit, tendency towards saving, and discipline in work, mobility in work, and having desire for more income. The reduction in value of domestic currency leads to a net increase in exports on one hand and reduces total supply by increasing the prices of imported inputs on the other hand. Therefore, the net effect of the reduction in value of domestic currency on production will depend on the fact that to what extent the demand and supply change. In other words, if the increase in total demand exceeds the total supply reduction, it will have an expansionary effect on production, but if the rate of reduction in total supply exceeds the increase in total demand, it will have contraction effect on production. The neutral effect of exchange rate changes on production occurs when the changes in total demand are equal with changes in total supply are equal and they neutralize the effect of each other on production (Bahmani Oskouie, 1993: 2). Differences in the determination of the effect of the exchange rate on production are expressed through absorption and monetary control approaches. The basic assumptions of these models are the flexibility of the price, the degree of using the capacity, and the emphasis on the demand side of the economy.

\section{Capital market development}

The stock market has grown dramatically in recent decades so that the total capital of these markets in the world has increased from less than $\$ 1$ trillion in 1974 to more than $\$$ 17 trillion by the end of 1997. Moreover, the annual turnover of the stock increased from \$ 3.4 billion in 1974 to $\$ 11$ trillion in 1997. The experience and the role of the stock market in developed countries in recent decades on the 1918 one hand and the publication of the above-mentioned studies on the other hand made the developing countries create a stock market. The stock market in Iran started its activity again since the beginning of 1991 after a short period of time. Over the 24 years since the start of the re-activity of the stock market in Iran, the statistics presented on the capital market value shows that the stock market in Iran has had a good growth rate, but market activists are well aware that lack of reforming these misleading statistics threatens not only the entire market but also the entire economy of the country. Without doubt, the bubble increase of price of some stocks at different periods of times and the recession in the market, and as a result, the loss of shareholders should be sought in weakness of such rules and regulations. Lack of proper structure in the stock has made some activists in this sector think on their personal interest, rather than trying to work in line with stock goals, leading to frequent ups and downs in market in its short history.

To find the root of this situation, the analysis should be focused on the fact that the stock market is an economic entity in competitive economies, while Iran's economy is one of the most government-owned economies in the world, so that based on the figure reported in 2003, among the 155 countries of the world, Iran ranked 148 in the economic freedom index. The philosophy of the capital market is moving towards market growth and competition, while the size of the government is increasing in Iran annually. The presence of a large government allows some people to have greater space for market instability in line with their interests due to their dominance over the government-owned assets. Every country's economy is basically composed of three sectors: money market, capital market and the real sector of economy, and any change in each of these sectors will affect other sectors. Thus, the reform of the capital market is not limited to reform of mechanism of this sector of the economy, but also the reform of other sectors. Beyond the framework of the country's economy, other sectors should also be considered. For example, the legal system of the country plays a decisive role in the capital market. In this regard, we can refer to the trade law. As we know, the main players of the economy are companies (provided that the government abides its governance duties) and the framework for the activity of companies is the same as the trade law, approved on 1923/06/21. This law is in fact a translation and adaptation of the French Trade Law. The French trade law was reformed in France shortly after the adaptation by Iran. The law had 600 articles at that time, but the part of its companies, which included Articles 21 to 94 of the Trade Law, was replaced by the reform bill of the Trade Law approved on 1968/04/11 with 300 articles. This law has remained unchanged since 1968. The Trade Law is a major barrier to the transformation of the industrial and commercial enterprises of the country due to its old age and its lack of coordination with internal and external conditions. In this regard, we can refer to deficiencies and shortcomings such as parent companies, merging of

Mehdi Mardani ${ }^{1}$, AFMJ Volume 4 Issue 05 May 2019 


\section{"Evaluation of the Effect of Privatization on Financial Development and Company Growth"}

companies, integrated accounting, E-commerce, the Trade Law Court, and so on. Thus, as we observe, the reform of capital markets requires fundamental changes in other sectors (Darvish Zadeh, 2015).

\section{Minimum optimal scale and company growth pattern}

The minimum optimum scale refers to conditions in which the economic index for industry and trade is exploited at its maximum capacity. Thus, the minimum optimal scale is when the decreasing trend of the average long-term cost curve of the company stops. If the minimum optimal scale is considered small relative to market size, great number of small companies can continue to operate in a similar industry, but if it is supposed to be large, a few powerful companies can dominate the market. In this case, noneconomic indices will be placed under the minimum optimal scale. When a company return exceeds from a point below the minimum efficiency scale, that company will be more efficient and will experience higher economic index. Therefore, until the company reaches to a growth higher than optimal scale, the growth process must continue with intensity. In this regard, the ways to achieve growth, integration and acquisition are the most effective solutions to achieve the optimal minimum scale. Simon and Bonini (1958) stated that it is expected that the growth to be different from company size only if the company is at the top of the optimum minimum. In addition, Lotti et al. (2003) found that Gilbert's Law is not applicable to small companies in years when they are newly established, while this law is applied for the companies that have been enlarged enough to overcome the minimum optimal scale.

\section{Enterprise growth stages}

Like other creatures, an enterprise has a life cycle. Once born, it grows and eventually dies. One of the applied models for analyzing the position of enterprises is the method of determining the life cycle of enterprise. According to this model, each product, service, industry or business has a life cycle. It means that it is born and introduced at one period of time, grows, reaches to the stage of maturity, and then, it reaches to the saturation phase, and eventually, it declines. Therefore, once the position of each enterprise was identified, it should be planned in such a way that the enterprise to remain in their growth and maturity stages, since if it is not planned properly, it will result in the enterprise destruction. In general, the business life cycle consists of five stages: (birth, growth, maturity, decline, death). All enterprises do not go through necessarily all of these stages. Some enterprises never grow rapidly and die at birth. Some enterprises do not necessarily mature after rapid growth, and may die in the growth stage. Some others enter the stage of maturity after the growth stage and survive for many years. Additionally, these stages do not have a definite timing, and they depend on enterprise leadership model, management model, enterprise structure, resources, and many other variables.

\section{Life cycle model of organizations}

One of the applied models for analyzing the position of enterprises is the method of determining the life cycle of enterprise. According to this model, each product, service, industry or business has a life cycle. It means that it is born and introduced at one period of time, grows, reaches to the stage of maturity, and then, it reaches to the saturation phase, and eventually, it declines. Therefore, once the position of each enterprise was identified, it should be planned in such a way that the enterprise to remain in their growth and maturity stages. Life cycle theory is also applicable in cases such as products, market, technology, and industry. Thus, by determining the position of each of the above factors in the curve, a clear and accurate picture of the actions and measures which should made in the future can be obtained. It should be noted that in the formation of each stage of the organization's life, a number of factors including the mission of the organization, technology, organizational structure, organizational ownership, market status, and many other factors are directly involved.

The main stages of the organization's life cycle are:

-birth, development and introduction

-growth

-Maturity and saturation

-aging and decline

In the organization's life cycle curve, as the distance of growth period and maturity period is shorter, the role of research and development ( $\mathrm{R} \& \mathrm{D}$ ) activities will be higher, and $\mathrm{R} \& \mathrm{D}$ will play major role in such organizations. On the contrary, as the distance of growth period and the maturity period become longer, the role of $\mathrm{R} \& \mathrm{D}$ in these industries will be less. The steel industry is among this group of organizations. Another point about the life cycle curve is its widespread use in high technology industries. Based on the life cycle curve, if the industry has a high growth rate, the possibility to penetrate to market of its industry will increase and the market share can be increased as much as possible without affecting the sales of competitors, because the market has been completely saturated.

The life cycle curve of the organization has two basic weaknesses: first, the duration of two stages in the life cycle curve is different in different industries, and it is very difficult to determine which industry is at what stage at the present time, such as the difference in the duration of two stages in the life cycle curve of the two computer and steel industries. Second, through innovation, the companies can change the shape of their life cycle curve. In other words, before reaching to the stage of saturation, they will begin another stage of growth, such as Intel Company.

\section{Financial leverage and growth opportunities}

As there is no consensus in various theories explaining the company's capital structure, there is also no consensus on the relationship between company growth opportunities and its debt level. According to the trade theory (Kraus and 


\section{"Evaluation of the Effect of Privatization on Financial Development and Company Growth"}

Litzenberge, 1973), the use of debt can increase the probability of a bankruptcy, which may indicate a reduction in future growth opportunities. Hence, there may be a negative relationship between growth and opportunities and debt. Information asymmetry is associated with more growth opportunities than assets. As a result, when accumulated profits finished, hierarchical theory predicts the priority of debt to foreign stock for companies with high growth opportunities. According to Ross (1977), creditors recognize high growth opportunities for companies and provide them with favorable credit conditions. Thus, with regard to signaling theory, the expected relationship between company growth opportunities and debt is positive . According to the representation theory, the relationship between growth opportunities and debt can be positive or negative. In this regard, Stales (1990) refers to two types of costs related to company's growth opportunities: 1 . The costs caused by inadequate investment problems and 2 . The costs caused by over-investment problems. Therefore, the relationship between growth opportunities and debt can be negative (inadequate investment costs) or positive (overinvestment).

According to the first type of costs, Myers (1977) argues that shareholders / managers of companies with high growth opportunities have incentives to invest in high-risk projects. When the investment projects succeed, the shareholders / managers receive maximum returns, but when the projects fail, the creditors incur the maximum cost. The hypothesis of inadequate investment for companies with high growth opportunities leads to a negative relationship between growth opportunities and debt. Given the problems of overinvestment, Jensen (1986) and Stales (1990) concluded that companies with low growth opportunities have advantages in using debt as a way to given order to managers' actions, leading to reduced costs of free cash flows and ultimately a positive relationship between growth opportunities and debt.Hoakemiyan et al (2001) argued that companies with high growth opportunities would prefer to finance growth opportunities instead of debt through accumulated profits. As a result, the high possibility of a combination of assets in companies with high growth opportunities may make creditors limit their credibility to this type of company (Sinaei et al., 2011).

\section{Growth opportunities and dividend}

Usually, dividend is seen in companies that cannot invest their profits. Dividend depends on the investment policy of the company. Companies that have profitable investment opportunities (growth) consider profit as a source of financing. Lang and Litzenberger (1989) argue that the theory of signaling and the theory of free cash flows can greatly explain the effect of the dividend on value of the company, in the presence or absence of growth opportunities. The explanation of the signaling theory in this regard is based on the information symmetry between managers and investors. The result of the research conducted by Lopez \& Wiesenthe (2010) showed that in the case of growth opportunities, there is a negative relationship between the dividend and the value of the company. They argue that with the assumption of information symmetry and in the presence of growth opportunities, the dividend by the company can reduce internal resources, increase the need for foreign resources and finally reduce the company value. Hence, it is expected that in the case of growth opportunities, there is a negative relationship between dividend and company value. The result of Lopez \& Wiesenthe (2010) showed that in the absence of growth opportunities, there is a positive correlation between profit sharing and company value. Gursoy and Aydogan (2002) argue that, based on the free cash flow theory, the policy of dividend reduces the resources under the control of managers. Therefore, companies with no growth opportunities will be able to prevent the loss of scarce resources of the enterprise through dividend. Thus, in an enterprise with no growth opportunity, the company value is expected to be positively correlated with the dividend (Sinaei et al., 2011).

\section{Growth opportunities and ownership structure}

Cuervo (2000) argues that the effect of ownership structure on the value of a company is based on the conflict of interests among the shareholders. When the major shareholders have a good percentage of the stock, they can impose their policies on the company and attract private interests. When the rights of all shareholders are not observed equally, the ownership concentration in the control of a number of major shareholders will increase. Previous studies have indicated that major shareholders (controllers), in contrast to minority shareholders, have more control over the managers in order to improve the performance of the enterprise. Jayesh Kumar (2004) examined the effect of ownership structure on the value of companies in India and concluded managers had the highest effect on the company's performance and foreign shareholders and holding companies did not significantly affect the value of the company. Seifert (2000) in his investigation in UK, USA and Japan found that there was a significant relationship between the presence of major shareholders in the composition of the company ownership and the value of the company. In investigating the Chinses companies, Firth et al (2002) concluded that there was a significant relationship between controlling mechanisms in corporate governance and company value. Lopez and Wiesenthe (2010) argue that growth opportunities have an impact on the ability of major stakeholders in expropriation of funds from minority shareholders. In a study conducted for this purpose, they concluded that there was a nonlinear relationship between the ownership structure and the value of the company and growth opportunities increased the intensity of this nonlinear relationship. Based on the results of similar studies, it is expected to be a non-linear relationship between the ownership structure and the company value (positive effect 
due to management control and monitoring and negative effect through the expropriation of funds from minority shareholders), and also growth opportunities (private interests) have a significant effect on this relationship (Sinaei et al., 2011).

\section{Company growth theories}

The theories seeking to identify the main factors of growth of the companies can be divided into two main schools: the first school focuses on the effect of size and age of the company on growth and the second school focuses on the effect of variables such as strategy, market, characteristics of the owners of the company / managers, etc. In the first approach, the emphasis is on the effect of company size on growth through Gilbert's law (1931). However, the experimental results are very confusing. While some of the studies suggest a positive relationship between the variables (Acs, 1990), other studies suggest that the relationship between size and growth depends on the measurement instrument (Coria, 2003). Given what was stated above, the learning theory tries to explain these variables in order to reject or accept new factors such as the age of the company and the industry, and so on. However, in the past few years, various authors have made great efforts to find statistical rules in addition to various theories. The approach of another theory to factors of growth is the critical factors (success) perspective, which focuses on the main bottlenecks of the organization in its path to achieve the mission and vision. These factors are always explicit or hidden. The important issue is identifying them scientifically. If Gazal and other companies' managers are asked about the critical factors of their organization's success, each one will give different answers. Hence, growth may be viewed as a complex process of development and knowledge (Roemer 1986) and the result of identifying the key factors in companies may vary based on competence theory. This theory suggests that at several factors are effective for rapidly fast-growing in line with their longterm economic growth, including: a) entrepreneurs, b) inventors, c) innovators, d) craftsmen

Experience has shown that the introduction of new ideas within the economy and its development has important innovations in large-scale industries. In the current theory, there is another distinction between entrepreneurship and industry. The definition provided on ability in this theory forms a more business organization. Therefore, craftsmen play a key role in the growth of companies. Entrepreneurs and innovators can engage with craftsmen in some cases and evolve them, leading to growth of large companies.

Skilled force: Economic development and growth requires communication with the professional skills of employees, which is rapidly expanding in industries. However, most of these industries lack these skills. Another theoretical approach to this phenomenon is the approach that focuses on the systemic and strategic point of view. From this point of view, high growth in brief is the company's process and a strategic fit between the company and its environment. Based on this approach, external changes (in the technological environment, the market, and industrial characteristics, etc.) and internal changes (ownership objectives, motivational systems, organizational culture, etc.) will be linked to each other (Moradi Pour and Hosseinlu, 2011).

\section{Privatization}

Various definitions have been provided on the term privatization. Privatization is a process in which a government provides the conditions for transferring its functions and assets to the private sector. Privatization means the establishment of a new system based on market mechanisms and, as a result, development in various dimensions of the economy. Privatization in the concept of cultural dissemination means providing the conditions for increasing the participation of people at all levels in the economic affairs of society. Therefore, privatization is a comprehensive and diverse term that refers to the operational and financial control of public institutions and transferring it to the private sector. In other words, privatization is the elimination of any kind of control and interference in the establishment of the supply and demand mechanism. The transfer of ownership or control of economic enterprises from government to the private sector can also be considered as the definition of privatization (Ahmadi, 2011). With a glance at the various definitions of privatization, the concepts such as improvement of performance, transfer of ownership and management, liberalization, making the enterprises and companies market-oriented, creating conditions for full competition and eliminating government cumbersome rules can be considered for the privatization. Taking these concepts into account, we can introduce a common and general definition of the term privatization. Privatization is a process in which the efficiency of the market mechanism regains life and the performance of the economic activity of the government and the public sector is tested. During this process, it may lead to the restriction of the ownership or management of some of the government-owned economic units and transferring them to the market mechanism.

\section{Privatization goals}

In most countries, privatization was accepted as a way of rationalizing the economic structure, reducing the financial pressures of government units, increasing efficiency of resources, extending ownership, equipping financial resources, maximizing the use of existing specialties, strengthening work motivations, reducing bureaucracy, tackling deficits in balance of payments, gaining income, and reducing government's heavy burden of services, so that a large number of countries have implemented this policy are implementing it. The privatization goals in each country are taken based on the policies, economic programs and general strategies of the society. As economy strategies and programs vary from one country to another country, private 


\section{"Evaluation of the Effect of Privatization on Financial Development and Company Growth"}

privatization in each country seeks for specific national and native goals and specific goals may be prioritized in each country. In economically advanced and developed industrialized countries, the privatization process is follow the goals such as increasing efficiency, gaining income and reducing the financial burden of the government, while in developing countries, privatization follows broader goals and it must resolve the problems and bottlenecks due to underdevelopment problems and conditions. The most important goals of privatization in these countries include increasing resource efficiency, optimal use of financial resources of companies, reducing the government interference in the economy, allocating resources to the selfregulating mechanism of the market sector, confronting with wandering liquidity, creating a competitive and secure environment for long-term investments, access to new techniques of management, access to capital and foreign technology, and finally, the goals of wealth distribution and income.

Given what was stated, the most important privatization goals that have been highly considered and used include:

- Increasing competitiveness and improving efficiency in the management and operation of economic institutions

- Reducing the direct role of government in economic activities

- Reducing government expenditures caused by payment of subsidies and capital expenditures

-Development of domestic capital markets and access to capital, technology and foreign financial resources.

Reform, independence and flexibility in the management system and the transfer of ownership of government units to real and legal persons are expected from privatization process. Therefore, when privatization can lead to an increase in the internal efficiency of government-owned enterprises that will result in the transfer of ownership, otherwise, the most important goal of privatization (the increase in efficiency) would be neglected (Ahmadi, 2011). While the privatization of enterprises and institutions that have a monopoly situation increases the efficiency of the economic enterprises and institutions, it might reduce the efficiency of resource allocation at macro level, because private sector monopolies has been associated with this risk that the optimal allocation of resources at the community level to be disrupted and use their monopoly power in favor of individual and collective interests. Therefore, if privatized enterprises cannot be placed in competitive conditions, a shift between increasing the internal efficiency of the enterprise and the efficiency of resource allocation must be accepted (Azar and Islamjou, 2012). In general, special attention should be paid to the role of competition in the privatization process. Creating a competitive environment is the most important advantage, the best indicator and sign of life of the economic system. Any factor that prevents the creation of competitive conditions in the market will disrupt the normal functioning of the market mechanism and lead to inefficiencies in the governing economy. Privatization deals with defining new opportunities for private sector participation and economic activities, and reducing the volume of government ownership. In other words, the goal of privatizing is to reform the government structure and to eliminate the monopoly. Therefore, the privatization of any other goal other than these cases cannot be considered reasonable or at least economical.

\section{The history of privatization in Iran}

The start of privatization plans in Iran backs to implementation of the model and policies of economic adjustment of the International Monetary Fund and World Bank during the construction period. After the Islamic Revolution (led a large part of Iran's economy to be public), the size of the government gradually became larger. During the construction and implementation of economic adjustment policies and the implementation of the privatization model dictated by international organizations to overcome the crisis and achieve the appropriate economic growth, the first steps were taken to reduce the role of government in the market and the economy. For a successful privatization, the power and efficiency of the private sector should not be less than those of the government; otherwise, the main goal of privatization (an increase in efficiency) will not be realized.

\section{The reasons for privatization failure}

Lack of Ian's economic managers with privatization over the past 10 years and the lack of use of the experience of other countries in this regard have created a pessimistic view on "privatization" in people. Apart from exceptional cases, the private sector's performance in transferred units has led to increased unemployment, reduced production, reduced efficiency, employees' deprivation of government benefits, etc. Its main reasons are lack of knowledge of the Iran's economic managers on private sector, lack of comprehensive and systematic model for transferring and the lack of a strong private sector in the country, led to a wave of opposition to privatization among the working classes. The most important reasons for this failure are the inadequate understanding of the subject of privatization, the lack of a proper definition of it, and moving in a path without pre-determined perspective. Scientific studies suggest that the result of privatization is not same in all societies. For example, privatization in countries such as Canada, Malaysia, the Czech Republic, Poland, and partly in Nigeria has been successful, but in some other countries, such as India, it has given both negative and positive results. In India, some activities of private sector have resulted to positive results, while some others have given a negative result. The most important reasons for the failure of the government in the privatization in recent years can be examined at three levels:

-Level of values

-Level of norms

-Level of behaviors 


\section{"Evaluation of the Effect of Privatization on Financial Development and Company Growth"}

At the level of values, no basic work has been done to identify the need to downsize or privatize the body of the executive system. The second factor relates to the level of the norms. In the privatization process, we need communication with foreign companies. Therefore, we need to reform some of the rules and regulations. Foreign investment would be impossible without reviewing and reforming the legal structure of the country. At the behavioral level, improper behaviors have been seen unfortunately in the privatization in recent years. With regard to another weakness of privatization, it can be stated that many of the activities in which the private sector has a high potential remain still under the control of government and those areas are transferred to private sector, which there is no many customers for them. This has made some people speak on the inability of the private sector to replace the public sector. If companies with appropriate facilities, appropriate technology, educated and young work force with the ability to create creativity and public planning were provided to the private sector, the type of attitude toward privatization would have completely changed. Many of the companies that are currently shown profitable on paper are owed to the government's budget. The private sector is not simply a partner to government sector in failure so that anything that government does not want to transfer to it for private sector. Government should not transfer a firm or company that is not profitable to the private sector and hold the company which is profitable. The private sector never has a magic power, but it can only take advantage of the capacities available between the private sector and the government sector, which is mainly related to meritocracy. In privatization, there must be a link among the policy makers, decision makers and executives. What will happen in situation in which each of these does not do their job well and attributes their failure to lower rank people? However, privatization will not be the only factor in the success of the Iranian economy, but there is a fact that we should follow the principle of "modeling of the bests" that is common in the world. Investigating other countries suggests that the best economies belong to the countries that have been able to create a good mix of government, private, cooperative and non-government organizations. One of the most important issues of privatization is the pricing of companies and the transfer of these companies in the best possible way, something that has not been considered seriously so far. Any mistakes in the pricing of government units have negative outcomes. Under - pricing of these units reduces the value of government companies and over- pricing of them causes problem for the private sector and leads to dissolving of the companies. Moreover, transfer of the government units should not be such that the government transfers its bankrupted companies and institutions to the private sector s. such privatization will have a short life cycle. One of the serious problems is that there is a kind of private and cooperative $\mathrm{s}$ in some Iranian institutions and companies that are not consistent with any international companies, all 1923 of which have become a barrier to privatization (Azar and Eslamjou, 2012).

\section{Works done by successful countries after privatization}

Malaysia has created 18 regulatory organizations to regulate relationship between consumer and private sector and prevent the problems that may occur. India is also one of the countries that has taken measures in this regard and has set up monitoring boards to ensure that privatization is performed properly and that the activities of companies transferred to the private sector continue. What made it necessary to form monitoring bodies in India were the following cases.

- The possibility of creation of private monopolies

- The tendency to maximize the profit

- Supporting the consumer rights

- Preventing the loss of public properties

- Removing non-productive expenditures

- Paying attention to research, development or participation in technology change

After privatization, the government must take some measures to prevent privatization harms and ensure continuity of activities. These measures include:

- Purchasing shares and assets of companies in strategic sectors

- Transfer or reorganization of privatization

-Remaining the private sector as a service provider (Ahmadi, 2011).

The Relationship between theory and research variables The privatization policy has been implemented in developed and developing countries in recent decades. The favorable results of implementing this policy in developed countries, the collapse of highly centralized and government-owned economic systems, as well as policies of international economic organizations such as the International Monetary Fund and the World Bank, have made this policy to be implemented as one of the basic programs for reforming the economic structure in most countries of the world, especially in developing countries. Privatization is in fact a policy to balance the performance of the government compared to other economic sectors. Advocates of privatization believe that implementation of this policy will lead to an increase in government income by selling of government-owned enterprises and a reduction in budget deficit in the short term and advanced technology, increased efficiency and a strong private sector in the long term. Providing a competitive environment and developing a market-driven mechanism for all economic activities, privatization requires the private units to function more efficiently than the government sector. As a result, one of the most important goals of the implementation of the privatization program is improving the performance of the economic units transferred to non-government sector. The question asked here is whether the implementation of general principles of Article 44 of the constitution has led to improvement in the performance and profitability of 


\section{"Evaluation of the Effect of Privatization on Financial Development and Company Growth"}

companies transferred to the private sector. The objective of the research is assessing the success of the company in implementation of these policies and, if unsuccessful, finding the reasons and then providing the appropriate solution for it (Shariyati et al., 2016). Privatization is a process in which the government can transfer its duties and assets to the private sector and privatization means the establishment of a new system based on market mechanisms and transformation in different dimensions of the economy. Privatization in the concept of cultural dissemination means providing the conditions for increasing the participation of people at all levels in the economic affairs of the society. Hence, privatization is a comprehensive and diverse term that refers to the operational and financial control of government institutions and transferring them to the private sector. In other words, privatization involves elimination of any kind of control and interference in the establishment of the supply and demand mechanism. The transfer of ownership or control of economic enterprises from the government sector to the private sector can also be accepted as a definition for privatization (Mahdi, 2013). One of the key factors which can play a major in this regard is the capital market. In the major economies of the world, the capital market, as one of the most important economic institutions, has helped governments in the economic program. It is also one of the main roles in financing the country. Moreover, the evaluation of the performance of economic units accounts for a large part of accounting, management, economics, and so on. The performance has a direct relationship with goal. Financial development means measuring to what extent the economic unit has reached its predetermined goals in its programs. The result of the evaluation of the performance is not the goal but a tool used to predict future plans and to improve the strengths and resolve the weaknesses of that unit (Fama, 1980).Karami et al (2016) investigated the relationship between privatization and the development of financial markets in Iran's capital market. Moreover, Farzandi Ardakani et al (2015) explored the policies, concepts, dimensions, characteristics, challenges and strategies of the resistant economy. Rostam Khani and Hasanlu (2013) compared the performance of companies before and after the transfer. A review of studies conducted in the area of privatization and financial performance suggests that no research has investigated the effect of privatization on financial development and company growth so far. Hence, this research was conducted with the aim of evaluating the effect of privatization on financial development and company growth.

\section{Methodology}

One of the main requirements of any research is the availability of reliable information and the speed of accessing to it. This information provides an opportunity for research to follow up the process of studying and analyzing data with the aim of evaluating the research objectives and hypotheses. The information needed for this research was extracted by using a library method and financial statements and explanatory notes of the listed companies in the Tehran Stock Exchange (as one of the most important capital markets), annual reports of Tehran Stock Exchange, compact discs, including the information of the listed companies in the Stock Exchange between the years 2013 and 2017 and Stock Exchange policies. Theoretical topics of the research were collected through the study of theses, journals, books, and internal and external articles in libraries and the use of the Internet. The applied objectives of this research are helping the senior managers in identifying the factors affecting the financial development and the company growth, helping shareholders in identifying the role and status of privatization in financial development and company growth, helping the investors in identifying the effect of privatization on financial development and the growth of the company through the role of investors as the most important factors of privatization.

\section{Research Hypotheses}

Privatization has a significant effect on the financial development of the listed companies in Tehran Stock Exchange.

Privatization has a significant effect on the growth of the listed companies in Tehran Stock Exchange.

\section{Research population and sample}

The research population included all listed companies in Tehran Stock Exchange. The knockout method was used to select the research sample. In order to select the research final sample among the listed companies in Tehran Stock Exchange, companies with the following characteristics were selected:

1. Their financial year ends at the last day of the year.

2. During the research period, there is no change in the fiscal year and trading interruption for more than 3 months

3. It should not be among the investment, financial intermediation, leasing companies, and banks.

4. The company's financial information should be completely available for the tears 2013 to 2017 .

Based on the above-mentioned conditions, a total of 123 companies were selected as the sample company. Since each company has five sets of financial information extractable in financial statements, the total number of observations of all companies during 5 years was 615 . Its filtering table is as follows" 


\section{"Evaluation of the Effect of Privatization on Financial Development and Company Growth"}

Table (1): Filtering table (Source: Rahavard-e Nowin Software)

\begin{tabular}{|c|l|c|}
\hline row & Filtering & Company size \\
\hline & Total number of stock companies & 635 \\
\hline 1 & The companies that are not listed in the Stock Exchange since the late 2013 to end of 2017 & $(178)$ \\
\hline 2 & The companies that their fiscal years ends at the last year of the year & $(132)$ \\
\hline 3 & Their information is not available in the studied period & $(156)$ \\
\hline 4 & $\begin{array}{l}\text { The companies that are not among the investment, financial intermediation, leasing } \\
\text { companies, and banks }\end{array}$ & $(46)$ \\
\hline & Number of research sample & 123 \\
\hline
\end{tabular}

\section{Research Variables}

\section{Privatization $(\mathrm{P})$}

The independent variable of this research is privatization. In order to investigate the privatization process, the zero and one variable is used, so that if privatized company takes one, otherwise, it takes zero.

Financial development (FD)

The dependent variable of this research is the financial development and growth of the company. To investigate the financial development of the company, the market to book ratio is used. It is calculated as follows:

$$
\mathrm{MB}_{\mathrm{i}, \mathrm{t}}=\mathrm{MV}_{\mathrm{i}, \mathrm{t}} / \mathrm{BV}_{\mathrm{i}, \mathrm{t}}
$$

In which: MV is the stock market value and BV is the book value of the stock.

Company Growth $(\mathrm{G})$ :

In the present study, to calculate the growth, the total assets in the first period are deducted from the total assets at the end of the period, and then, the remainder is divided into the total assets of the first period (Fernandez, 2015):

$$
\mathrm{G}_{\mathrm{i}, \mathrm{t}}=\mathrm{TA}_{\mathrm{i}, \mathrm{t}} \mathrm{TA}_{\mathrm{i}, \mathrm{t}-\mathrm{l}} / \mathrm{TA}_{\mathrm{i}, \mathrm{t}-\mathrm{1}}
$$

In which: $\mathrm{TA}_{\mathrm{i}, \mathrm{t}}$ is total assets of the end of year and $\mathrm{TA}_{\mathrm{i}, \mathrm{t}-1}$ is total assets of company at the beginning of the year Financial leverage (Lev)

This index is calculated by dividing the total debts to total assets and it is calculated in this way:

$$
\mathrm{LEV}_{\mathrm{i}, \mathrm{t}}=\mathrm{TD}_{\mathrm{i}, \mathrm{t}} / \mathrm{TA}_{\mathrm{i}, \mathrm{t}}
$$

In which: TD is total debt of the company.

Size:

The size of the natural logarithm of the total assets of the company is calculated as follows:

$$
\operatorname{Size}_{\mathrm{i}, \mathrm{t}}=\log \left(\mathrm{TA}_{\mathrm{i}, \mathrm{t}}\right)
$$

Descriptive statistics of research variables

A summary of the descriptive statistics of model variables after screening is presented in Table 2.

Table 2: Descriptive statistics of research variables

\begin{tabular}{lllrrr}
\hline variable & Symbol & Number of observations & mean & SD & median \\
\hline Privatization & P & 615 & 0.396 & 0.138 & 0.000 \\
Financial development & FD & 615 & 4.438 & 1.085 & 0.272 \\
Company growth & G & 615 & 0.261 & 0.145 & 0.382 \\
Financial leverage & Lev & 615 & 03.64 & 0.26 & 0.096 \\
Company size & Size & 615 & 13.67 & 5.17 & 10.505 \\
\hline
\end{tabular}

Table (3): The results of the normality test of the dependent variable at the level of companies

\begin{tabular}{|l|c|c|c|c|}
\hline Dependent variable & Error term \\
\hline Dependent variable & Jarque-Bera statistic & Probability & Jarque-Bera statistic & Probability \\
\hline Financial development & 2.795042 & 0.031850 & 3.338962 & 0.041863 \\
\hline Company growth & 3.336951 & 0.028965 & 3.285501 & 0.032857 \\
\hline
\end{tabular}

Results of research hypotheses test

The results of the first hypothesis test

$$
\mathrm{FD}_{\mathrm{i}, \mathrm{t}}=\alpha_{0}+\alpha_{1} \mathrm{P}_{\mathrm{i}, \mathrm{t}}+\alpha_{2} \operatorname{size}_{\mathrm{i}, \mathrm{t}}+\alpha_{3} \operatorname{Lev}_{\mathrm{i}, \mathrm{t}}+\varepsilon_{\mathrm{i}, \mathrm{t}}
$$

Table (4): Chow and Hausman test results for model (1)

\begin{tabular}{lcccc} 
test & Statistic & $\begin{array}{c}\text { Statistic } \\
\text { value }\end{array}$ & df & P-Value \\
\hline Chow & $F$ & 2.5694 & $(505 ، 101)$ & 0.0389 \\
\hline Hausman & $\chi^{2}$ & 4.00083 & 5 & 0.0284 \\
\hline
\end{tabular}


"Evaluation of the Effect of Privatization on Financial Development and Company Growth"

Table 5: Results of tests related to statistical assumptions of model (1)

\begin{tabular}{|c|c|c|c|c|}
\hline \multicolumn{2}{|c|}{ Statistic Ramsey } & Durbin-Watson statistic & \multicolumn{2}{c|}{ Breusch-Pagan statistic } \\
\hline$P-$ Value & $F$ & D & $P$-Value & $F$ \\
\hline \hline 0.6831 & 3.7844 & 1.92 & 0.0284 & 6.0749 \\
\hline
\end{tabular}

According to the results of Chow and Hausman tests as well data method and fixed effect method. The results of the as the results of the testing the statistical assumptions of the classical regression, the model (1) is estimated using panel

model estimation are presented in Table (6).

Table 6: Results of the first hypothesis test using fixed effects method

\begin{tabular}{|rrrrr|}
\hline \begin{tabular}{l} 
Dependent variable: financial development \\
Number of observations: 635 year-company \\
\hline Variable
\end{tabular} Coefficient & Statistic & P-Value & Relationship \\
\hline Fixed element & 0.4923 & $12 . / 3482$ & 0.0000 & Positive \\
\hline Privatization & 0.1954 & 8.1673 & 0.0421 & Positive \\
\hline Financial leverage & -0.1891 & -3.2298 & 0.3891 & Non-significant \\
\hline Size & 0.0482 & 3.8782 & 0.3994 & Non-significant \\
\hline & Model coefficient of determination & 0.8134 \\
\hline & & statistic $F$ & 4.4671 \\
& & $(P-$ Value $)$ & $(0.0000)$ \\
\hline
\end{tabular}

Therefore, according to the analyses performed with regard to the confirmation of the first hypothesis of the research, it can be concluded that privatization has a significant effect on financial development of companies. Karami et al (2016) showed that privatization has a significant effect on the development of financial markets in Iran's capital market.
Silveri (2000) has shown that the effect of privatization on the performance of companies has begun since 1989 and has taken a new form in recent years.

The results of the second hypothesis test

$$
\mathrm{G}_{\mathrm{i}, \mathrm{t}}=\alpha_{0}+\alpha_{1} \mathrm{P}_{\mathrm{i}, \mathrm{t}}+\alpha_{2} \operatorname{size}_{\mathrm{i}, \mathrm{t}}+\alpha_{3} \operatorname{Lev}_{\mathrm{i}, \mathrm{t}}+\varepsilon_{\mathrm{i}, \mathrm{t}}
$$

Table (7): Chow and Hausman test results for model (2)

\begin{tabular}{ccccc} 
Test & Statistic & Statistic value & $\mathrm{df}$ & P-Value \\
\hline Chow & $F$ & 5.0814 & $(505 ، 101)$ & 0.0284 \\
\hline Hausman & $\chi^{2}$ & 3.3862 & 5 & 0.0361 \\
\hline
\end{tabular}

Table (8): Results of tests related to statistical assumptions of model (2)

\begin{tabular}{|c|c|c|c|c|}
\hline \multicolumn{2}{|c|}{ Statistic Ramsey } & Durbin-Watson statistic & \multicolumn{2}{c|}{ Breusch-Pagan statistic } \\
\hline P-Value & $F$ & D & $P$-Value & $F$ \\
\hline \hline 0.3895 & 4.2774 & 1.85 & 0.0371 & 3.1385 \\
\hline
\end{tabular}

According to the results of Chow and Hausman tests as well as the results of the testing the statistical assumptions of the classical regression, the model (2) is estimated using panel data method and fixed effect method. The results of the model estimation are presented in Table (9).

Table 9: Results of the second hypothesis test using fixed effects method

\begin{tabular}{|rrrrr|}
\hline $\begin{array}{l}\text { Dependent variable: company growth } \\
\text { Number of observations: 635 year-company } \\
\text { Variable }\end{array}$ & Coefficient & statistict & P-Value & Relationship \\
\hline Fixed element & 0.6605 & 10.1558 & 0.0000 & Positive \\
\hline Company growth & 0.2517 & 1.4892 & 0.0184 & positive \\
\hline Financial leverage & 0.1482 & 1.4683 & 0.0256 & positive \\
\hline Company size & 0.0796 & 1.2265 & 0.0143 & positive \\
\hline & Model coefficient of determination & 0.7893 \\
\hline & & statistic $F$ & 5.2477 \\
& & $(\boldsymbol{P}$-Value $)$ & $(0.0000)$ \\
\hline
\end{tabular}




\section{"Evaluation of the Effect of Privatization on Financial Development and Company Growth"}

Therefore, according to the analyses performed with regard to the confirmation of the second hypothesis of the research, it can be concluded that privatization has a significant effect on company growth of the companies. The results of this research are different from those of the research conducted by Rostam Khani and Hasanlu (2013). Rostam Khani and Hasanlu (2013) showed that privatization increased the return on equity and reduced the growth rate of net profit and the ratio of sales to total assets, while it had no effect on the growth rate of net sales. The statistical results of the analyses suggest that privatization goals have not been achieved in the studied companies.

\section{Research Recommendations}

After performing the scientific research stages, if the research has been conducted systematically by researchers, the researcher can apply his or her own views on the results and provide solutions and recommendations in order to improve and expand the future research. For this reason, some recommendations are presented in accordance with the results of the research and for future research.

\section{Recommendations derived from the research hypotheses} test

Based on the results of the present study, associated with high correlation coefficient of all variables, we can refer to the following cases:

-Based on the results of the main hypothesis, it is recommended for managers and shareholders to use the financial development and company growth as an appropriate alternative to study privatization considering the importance of privatization in companies, since the research results showed that that the variable of financial development and company growth provide the necessary information for explaining the privatization.

-Based on the first hypothesis, it is recommended to use the financial development index to investigate the privatization of companies. The results revealed that financial development has the information to explain the variations in privatization. In fact, all beneficiaries can predict the privatization of the company and its variations by examining the financial development of the company.

-Based on the second hypothesis, it is recommended to use the growth factor of the company to examine the privatization. The results of the second sub-hypothesis showed that the company's growth has the information to explain the variations in privatization.

\section{Recommendations for future studies}

-identifying the effect of voluntary disclosure on financial development and company growth

-Investigating the effect of audit quality on the relationship between privatization and financial development and company growth.

\section{References}

1. Mohammadpour Zarandi, ME, Turkman Ahmadi, $\mathrm{M}$, The role of privatization in Iran's economy on deepening of stock market (with anemphasis on liquidity ratio) (Journal of Financial Engineering and Management of Securities Issue 35 / Summer 2018

2. Dadgar, Y, Nazari, R, Evaluation of Financial Development Indices in Iran

3. Sinaei, HA, Salagi, M, Mohammadi, K, The Effect of Growth Opportunities on the Relationship between Capital Structure, Dividend and Valuable Ownership Structure", Journal of Financial Accounting Research, Third Year, No. 4, Serial No. (10), Winter 2011-pp.4-87

4. Investigating the Impact of Privatization on Financial and Operational Performance of Privatized Government Listed Companies in Tehran Stock Exchange

5. Karami, G, Fathi Abdollahi, A, Bahri, J, Public Accounting, Volume 2, Issue 3, Autumn and Winter 2015

6. Bahmani Oskuei, M (2004), The macroeconomic effects of foreign exchange depreciation in the Iranian Rial during the post-revolution period, The third monetary and currency policy conference of monetary and banking research institutes.

7. Shafiee, MJ, Zara Pisheh, Z, The role of privatization and liberalization of economy in resilient economy of the national conference. Investigating and explaining the resistant economy (Year: 2012)

8. Fakhari, Kh, Yousefnejad, S, Investigating the relationship between systematic risk and earnings growth in Tehran Stock Exchange, Autumn 2006, p. 89

9. Moradipour, H, Hasanlu, H, Identification of Factors Influencing the Rapid Growth of Companies: Case Study of Behestan Daru Company, Specialized Journal of Parks and Growth Centers, Volume 8, Issue 29, Winter 2011

10. Azar, A, Eslamjou, A (20130, Comparison of the Performance of Companies Transferred to Private and Non-government Sector in Tehran Stock Exchange, Islamic Financial Research, Issue 1, Second Edition, Spring and summer 2012, pp. 5-9

11. Darvishzadeh, MH, Ghelsi, MN, Ashrafi, AN, Ebrahimi, M, Analytical Review of Investment Funds, The First International Management and Accounting Conference with Value-creation Approach (Year: 2015)

12. Fama, E., and K. French. 1998. "Taxes, Financing Decisions, and Firm Value."

13. Journal of Finance 53, no. 3: 819-843 


\section{"Evaluation of the Effect of Privatization on Financial Development and Company Growth"}

14. Cuervo, A. 2002. "Corporate Governance Mechanisms: A Plea for Less Code of Good Governance and More Market Control" An International Review". 10, no. 2:

15. Lang, L.H.P., and R.H. Litzenberger. 1989. "Dividend Announcements: Cash Flow Signaling Versus Free Cash Flow Hypothesis." Journal of Financial Economics 24, no. 1: 181-191

16. Lopez Iturriaga, Felix and Vecente Crisostomo (2010), "Do Leverage, Dividend Payout, and Ownership Concentration Influence Firms' Value Creation?" Emerging Markets Finance \& Trade / May-June 2010, Vol. 46, No. 3, pp. 80-94.

17. Jayesh Kumar.(2004).”Does Ownership Structure influence firm value?:Evidence from India",Indira Gandhi Institute of Development Research, India

18. Bruce Seifert, Halit Gonence and Jim Wright (2002)."The international evidence on Performance and Equity Ownership by Insiders, Blockholders and Institute". Old Dominion Universit

19. Gursoy, G., and K. Aydogan. 2002. "Equity Ownership Structure, Risk Taking, and Performance." Emerging Markets Finance and Trade 38, no. 6: 6-25.

20. Michael Firth,Peter M.Y.Fung and Oliver M.Rui.(June 2002).” Simultaneous Relationship among Ownership, Corporate Governance and Financial performance", Faculty of business and information systems, Hong Kong Polytechnic Univesity, pp 3-5,10-14

21. Jensen, M.C, Meckling, w. H, (1976), "Theory of the Firm: Managerial Behavior, Agency Costs and Ownership Structure". Journal of Financial Economics, 3(1), PP. 305-360

22. Myers, S. C, (1977), "Determinants of Corporate Borrowing", Journal of Financial Economics,5(2), PP. 147-175

23. Levine, Ross.( (१९४), Financial development and economic growth, journal of economic literature, 35, 688-726

24. Levine Ross, et al (2000), financial intermediation and growth, Journal of Monetary Economics 46, 31-77

25. Hao, C. (2006). Development of Financial Intermediation and Economic Growth: the Chinese Experience. China Economic Review, 17(4): $347-$ 362.

26. Levine, R. (1997). Financial Development and Economic Growth: Views and Agenda. Journal of Economic Literature, 35(2): 688- 72 